\title{
GAMIFICATION ELEMENTS AND THEIR IMPACTS ON TEACHING AND LEARNING - A REVIEW
}

\author{
Mohd Hishamuddin Abdul Rahman, Ismail @ Ismail Yusuf Panessai, \\ Noor Anida Zaria Mohd Noor and Nor Syazwani Mat Salleh \\ Department of Computing, Faculty of Art, Computing \& Creative Industry, \\ Universiti Pendidikan Sultan Idris, Tanjung Malim, Perak, Malaysia
}

\begin{abstract}
This paper discusses the results of a literature review to identify the elements of gamification in learning that have been applied in previous studies and their impacts on student learning, with only taking into account the related studies within the last three years (2016 to 2018). This is done to determine the most effective and suitable elements of gamification to be applied in our study and at the same time to identify research gaps that need to be fulfilled in future researches. The results of this review show that gamification has positive impact on student learning particularly in their engagement and achievement. Furthermore points, leaderboard and digital badge are the most applied gamification elements in the studies. The findings will be used as a guide for us in designing a gamified collaborative learning activities in the 3-dimensional virtual world that will be carried out later.
\end{abstract}

\section{KEYWORDS}

Gamification, Game-based Learning, Virtual World

\section{INTRODUCTION}

Today, gamification is not a strange word as it has been applied in various fields such as health, finance, entertainment, education and so on [1]. When seen in the context of education, gamification and game-based learning (GBL) are learning activities that are gaining popularity among educators, particularly in higher education [2]. Search from Google Trends shows that gamification and GBL are fairly consistent from year to year and this proves that they are among the topics that have always caught the attention of educators [3]. Built by emphasizing those elements that are common in a game into learning activities, this method can be carried out either physically or digitally by using various forms of technology.

\section{GAMIFICATION IN TEACHING AND LEARNING}

According to Hoe [4], a gamified learning activity allows students to acquire knowledge, hone skills and foster positive traits through the game built specifically for the purpose of learning. In other words, gamification in learning activities is a student-centred process [1]. It has been applied in all levels of education, from school level to higher education level [2]. Although it is often thrown with negative perspectives from the society especially from the parents of the students, the reputations of gamification and GBL remain intact. 
The International Journal of Multimedia \& Its Applications (IJMA) Vol.10, No.6, December 2018

It is not surprising when gamification is best suited to be practiced in today's learning scenario, which is no longer a teacher-centred but rather an emphasis on active student activities [5]. Hence, this is where the advantage of gamification is prominent because this method can provide various forms of stimuli to students, especially to involve and motivate them to stay active while studying. As explained by Alsawaier [6], gamification has a significant relationship with student motivation and engagement in learning, and therefore also has a positive impact on student achievement. It is also supported by Chan et al. [7], Dichev and Dicheva [1], Sepehr and Head [8], and also Szegletes et al. [9]. This is because gamification contains some form of elements that attempt to give a boost to the students, such as challenges, rewards, points, levels, options, and badges [4], [6], [10].

Seeing the advantages possessed by gamification in stimulating students, we are planning on applying it elements in our future research on gamification in teaching and learning. In order to achieve that, this study was conducted to review on gamification that have been carried out in recent years. This was to make sure that our study is up to date and in line with the current trend of research in gamification. There were two main focuses of this study; 1) to identify the gamification elements which were applied in the reviewed studies, and 2) their impacts on the learning outcomes. The findings will give us more insights on what gaps need to be fulfilled and also will assist us in determining the best elements of gamification to be applied in our studies.

\section{Methodology}

To achieve the objectives of this study, we accessed electronic databases such as ScienceDirect, Springer, Taylor and Francis, Emerald and Google Scholar to search articles related to gamification, published over the past three years (2016 to 2018) to ensure that information obtained is up-to-date. Keywords used were 'gamification', 'learning' and 'education'. The results were then filtered to ensure that only articles that we felt related were selected where the articles in the form of concepts and surveys were not taken into account. Only articles in the form of study or research that clearly state how the elements of gamification applied in teaching and learning activities were taken into account.

As a result, there were a total of 22 articles that meet the specified criteria. These selected articles have been analyzed in this study to identify the elements of gamification, which have been implemented by the researchers and the impacts of its implementation towards student learning outcomes. The results have been reported in the next section.

\section{FINDINGS AND DISCUSSION}

The findings of the analysis on the selected papers are as listed in Table 1, followed by a detailed discussion of these findings. Overall, the studies listed in Table 1 have implemented the elements of gamification in the process of teaching and learning, but in a different context. There were 15 studies conducted for university level and seven studies for school level and young children. For example, the study Spires \& Lester [15], Khan et al. [19] and Lam et al. [29] have been carried out to the students at the school level whereas the study of Huang et al. [27], Pechenkina et al. [21] and Tsay et al. [5] were on students at the tertiary level. This indicates that gamification is appropriate for being practiced for every student age group, especially students of $\mathrm{X}, \mathrm{Y}$, and Alpha Generation. Thus, it dismisses the stereotypes that games are only for kids. 
The International Journal of Multimedia \& Its Applications (IJMA) Vol.10, No.6, December 2018

Table 1. List of recent articles related to gamification in education from 2016 to 2018

\begin{tabular}{|c|c|c|c|c|}
\hline Researcher(s) & Research focus & Target user & $\begin{array}{l}\text { Gamification } \\
\text { elements }\end{array}$ & $\begin{array}{l}\text { Affected } \\
\text { learning } \\
\text { outcome: }\end{array}$ \\
\hline $\begin{array}{l}\text { Cózar- } \\
\text { Gutiérrez \& } \\
\text { Sáez-López } \\
{[11]}\end{array}$ & $\begin{array}{l}\text { To study the impacts of } \\
\text { gamification and GBL using } \\
\text { MinecraftEdu towards } \\
\text { engagement, interest and } \\
\text { motivation in social science } \\
\text { education }\end{array}$ & $\begin{array}{l}\text { University } \\
\text { students }\end{array}$ & $\begin{array}{l}\text { Challenge, } \\
\text { Collaboration }\end{array}$ & $\begin{array}{l}\text { Enjoyment, } \\
\text { Involvement, } \\
\text { Motivation }\end{array}$ \\
\hline $\begin{array}{l}\text { Gonzalez et } \\
\text { al. [12] }\end{array}$ & $\begin{array}{l}\text { Applying gamification elements } \\
\text { in healthy lifestyle education. }\end{array}$ & $\begin{array}{l}\text { Children (age } \\
8 \text { to } 12 \text { ) }\end{array}$ & $\begin{array}{l}\text { Challenge, } \\
\text { Digital badges, } \\
\text { Feedback, } \\
\text { Points \& rewards, } \\
\text { Leaderboard }\end{array}$ & Motivation \\
\hline $\begin{array}{l}\text { Hew et al. } \\
{[13]}\end{array}$ & $\begin{array}{l}\text { To study the effects of } \\
\text { gamification to students at the } \\
\text { Universities in Asia. }\end{array}$ & $\begin{array}{l}\text { University } \\
\text { students }\end{array}$ & $\begin{array}{l}\text { Digital badges, } \\
\text { Points \& rewards, } \\
\text { Leaderboard }\end{array}$ & $\begin{array}{l}\text { Result \& } \\
\text { achievement, } \\
\text { Engagement }\end{array}$ \\
\hline $\begin{array}{l}\text { Pesare et al. } \\
{[14]}\end{array}$ & $\begin{array}{l}\text { Applying gamification and } \\
\text { GBL in the context of medical } \\
\text { education to encourage } \\
\text { engagement and motivation. }\end{array}$ & $\begin{array}{l}\text { Professional } \\
\text { figures and } \\
\text { patients }\end{array}$ & $\begin{array}{l}\text { Challenge, } \\
\text { Points \& rewards, } \\
\text { Leaderboard }\end{array}$ & $\begin{array}{l}\text { Result \& } \\
\text { achievement, } \\
\text { Motivation }\end{array}$ \\
\hline $\begin{array}{l}\text { Spires \& } \\
\text { Lester [15] }\end{array}$ & $\begin{array}{l}\text { To study the effects of GBL in } \\
\text { Science education regarding } \\
\text { engagement, understanding and } \\
\text { problem-solving skills. }\end{array}$ & $\begin{array}{l}\text { School } \\
\text { students }\end{array}$ & $\begin{array}{l}\text { Challenge, } \\
\text { Exploration, } \\
\text { Points \& rewards, } \\
\text { Storytelling }\end{array}$ & $\begin{array}{l}\text { Result \& } \\
\text { achievement, } \\
\text { Engagement }\end{array}$ \\
\hline $\begin{array}{l}\text { Barna \& } \\
\text { Fodor }[16]\end{array}$ & $\begin{array}{l}\text { To study the effectiveness of } \\
\text { gamification in Moodle as a } \\
\text { learning platform for IT } \\
\text { courses. }\end{array}$ & $\begin{array}{l}\text { University } \\
\text { students }\end{array}$ & $\begin{array}{l}\text { Collaboration, } \\
\text { Feedback, } \\
\text { Points \& rewards }\end{array}$ & $\begin{array}{l}\text { Result \& } \\
\text { achievement, } \\
\text { Satisfaction, } \\
\text { Engagement }\end{array}$ \\
\hline Chan et al. [7] & $\begin{array}{l}\text { To study the benefits of } \\
\text { gamification in lessons in the } \\
\text { form of constructivism by using } \\
\text { GIGAME in legal theory } \\
\text { lessons. }\end{array}$ & $\begin{array}{l}\text { University } \\
\text { students }\end{array}$ & $\begin{array}{l}\text { Challenge, } \\
\text { Immediate } \\
\text { feedback, } \\
\text { Points \& rewards, } \\
\text { Leaderboard }\end{array}$ & $\begin{array}{l}\text { Result \& } \\
\text { achievement, } \\
\text { Satisfaction, } \\
\text { Enjoyment }\end{array}$ \\
\hline $\begin{array}{l}\text { Ding et al. } \\
{[17]}\end{array}$ & $\begin{array}{l}\text { To study the impacts of } \\
\text { gamification towards student } \\
\text { engagement on online student } \\
\text { discussions. }\end{array}$ & $\begin{array}{l}\text { University } \\
\text { students }\end{array}$ & $\begin{array}{l}\text { Digital badges, } \\
\text { Points \& rewards, } \\
\text { Leaderboard } \\
\text { Exp system }\end{array}$ & $\begin{array}{l}\text { Motivation, } \\
\text { Engagement }\end{array}$ \\
\hline $\begin{array}{l}\text { Dochie et al. } \\
{[18]}\end{array}$ & $\begin{array}{l}\text { To study the effects of } \\
\text { gamification on the building of } \\
\text { soft skills in students }\end{array}$ & $\begin{array}{l}\text { University } \\
\text { students }\end{array}$ & $\begin{array}{l}\text { Points \& rewards, } \\
\text { Leaderboard }\end{array}$ & Motivation \\
\hline $\begin{array}{l}\text { Khan et al. } \\
{[19]}\end{array}$ & $\begin{array}{l}\text { To study the effects of GBL } \\
\text { and gamification on } \\
\text { engagement and student } \\
\text { achievement in science lessons. }\end{array}$ & $\begin{array}{l}\text { School } \\
\text { students }\end{array}$ & $\begin{array}{l}\text { Challenge, } \\
\text { Immediate } \\
\text { feedback, } \\
\text { Points \& rewards }\end{array}$ & $\begin{array}{l}\text { Result \& } \\
\text { achievement, } \\
\text { Engagement }\end{array}$ \\
\hline $\begin{array}{l}\text { Leftheriotis et } \\
\text { al. [20] }\end{array}$ & $\begin{array}{l}\text { To study the effects of } \\
\text { gamification by using } \\
\text { interactive displays in lessons } \\
\text { regarding satisfaction, } \\
\text { enjoyment, and student }\end{array}$ & $\begin{array}{l}\text { School } \\
\text { students }\end{array}$ & $\begin{array}{l}\text { Challenge, } \\
\text { Collaboration, } \\
\text { Points \& rewards }\end{array}$ & $\begin{array}{l}\text { Satisfaction, } \\
\text { Pleasure, } \\
\text { Engagement }\end{array}$ \\
\hline
\end{tabular}


The International Journal of Multimedia \& Its Applications (IJMA) Vol.10, No.6, December 2018

\begin{tabular}{|c|c|c|c|c|}
\hline & engagement. & & & \\
\hline $\begin{array}{l}\text { Pechenkina et } \\
\text { al. [21] }\end{array}$ & $\begin{array}{l}\text { Examine whether the use of } \\
\text { gamified mobile learning in } \\
\text { affects achievement and student } \\
\text { engagement. }\end{array}$ & $\begin{array}{l}\text { University } \\
\text { students }\end{array}$ & $\begin{array}{l}\text { Digital badges, } \\
\text { Feedback, } \\
\text { Leaderboard }\end{array}$ & $\begin{array}{l}\text { Result \& } \\
\text { achievement, }\end{array}$ \\
\hline $\begin{array}{l}\text { Rawendy et } \\
\text { al. [22] }\end{array}$ & $\begin{array}{l}\text { Using gamification in learning } \\
\text { the Chinese language. }\end{array}$ & $\begin{array}{l}\text { School } \\
\text { students }\end{array}$ & Points \& rewards & $\begin{array}{l}\text { Result \& } \\
\text { achievement, }\end{array}$ \\
\hline $\begin{array}{l}\text { Sitra et al. } \\
\text { [23] }\end{array}$ & $\begin{array}{l}\text { Review the benefits of applying } \\
\text { gamification related to lessons } \\
\text { for special needs students. }\end{array}$ & $\begin{array}{l}\text { School } \\
\text { students with } \\
\text { special needs }\end{array}$ & Digital badges, & $\begin{array}{l}\text { Engagement, } \\
\text { Attitude }\end{array}$ \\
\hline Yildirim [24] & $\begin{array}{l}\text { To study the effects of the } \\
\text { gamification of teaching } \\
\text { methods on lessons to students. }\end{array}$ & $\begin{array}{l}\text { University } \\
\text { students }\end{array}$ & $\begin{array}{l}\text { Digital badges, } \\
\text { Points \& rewards } \\
\text { Leaderboard }\end{array}$ & $\begin{array}{l}\text { Result \& } \\
\text { achievement, } \\
\text { Attitude }\end{array}$ \\
\hline $\begin{array}{l}\text { Bovermann } \\
{[25]}\end{array}$ & $\begin{array}{l}\text { To study the effects of the } \\
\text { application of the concept of } \\
\text { gamification in the seminars for } \\
\text { long distance higher education } \\
\text { towards motivation and } \\
\text { engagement. }\end{array}$ & $\begin{array}{l}\text { University } \\
\text { students }\end{array}$ & $\begin{array}{l}\text { Points \& reward, } \\
\text { Leaderboard }\end{array}$ & $\begin{array}{l}\text { Motivation, } \\
\text { Engagement }\end{array}$ \\
\hline $\begin{array}{l}\text { Denny et al. } \\
{[26]}\end{array}$ & $\begin{array}{l}\text { To study the effects of the } \\
\text { application of gamification } \\
\text { elements in online learning } \\
\text { tools towards students' } \\
\text { performance in examinations. }\end{array}$ & $\begin{array}{l}\text { University } \\
\text { students }\end{array}$ & $\begin{array}{l}\text { Digital badges, } \\
\text { Points \& rewards }\end{array}$ & $\begin{array}{l}\text { Engagement, } \\
\text { Result \& } \\
\text { achievement }\end{array}$ \\
\hline $\begin{array}{l}\text { Huang et al. } \\
\text { [27] }\end{array}$ & $\begin{array}{l}\text { To study the effects of } \\
\text { gamification on student } \\
\text { engagement in lessons via } \\
\text { flipped-classroom. }\end{array}$ & $\begin{array}{l}\text { University } \\
\text { students }\end{array}$ & $\begin{array}{l}\text { Challenges, } \\
\text { Digital badges, } \\
\text { Immediate } \\
\text { feedback, } \\
\text { Leaderboard, }\end{array}$ & $\begin{array}{l}\text { Result \& } \\
\text { achievement, } \\
\text { Engagement }\end{array}$ \\
\hline $\begin{array}{l}\text { Kyewski \& } \\
\text { Krämer [28] }\end{array}$ & $\begin{array}{l}\text { To study the effect of digital } \\
\text { badges in different learning } \\
\text { situations. }\end{array}$ & $\begin{array}{l}\text { University } \\
\text { students }\end{array}$ & Digital badges & $\begin{array}{l}\text { Result \& } \\
\text { achievement, } \\
\text { Engagement }\end{array}$ \\
\hline $\begin{array}{l}\text { Lam et al. } \\
\text { [29] }\end{array}$ & $\begin{array}{l}\text { To study the effects of blended } \\
\text { learning and gamification } \\
\text { regarding argumentative } \\
\text { writing students. }\end{array}$ & $\begin{array}{l}\text { School } \\
\text { students }\end{array}$ & $\begin{array}{l}\text { Points \& rewards, } \\
\text { Leaderboard }\end{array}$ & Engagement \\
\hline Tsay et al. [5] & $\begin{array}{l}\text { Assessing the use of } \\
\text { gamification element in a } \\
\text { student-centred learning } \\
\text { environment for Self } \\
\text { Development and } \\
\text { Professionalism lessons. }\end{array}$ & $\begin{array}{l}\text { University } \\
\text { students }\end{array}$ & $\begin{array}{l}\text { Challenge, } \\
\text { Digital badges, } \\
\text { Immediate } \\
\text { feedback, } \\
\text { Leaderboard }\end{array}$ & $\begin{array}{l}\text { Result \& } \\
\text { achievement, } \\
\text { Engagement }\end{array}$ \\
\hline $\begin{array}{l}\text { White \& } \\
\text { Shellenbarger } \\
{[30]}\end{array}$ & $\begin{array}{l}\text { Review the use of gamification } \\
\text { elements (digital badges) in } \\
\text { nursing education. }\end{array}$ & $\begin{array}{l}\text { University } \\
\text { students }\end{array}$ & Digital badges & $\begin{array}{l}\text { Result \& } \\
\text { achievement, }\end{array}$ \\
\hline
\end{tabular}


The International Journal of Multimedia \& Its Applications (IJMA) Vol.10, No.6, December 2018

All the studies that were reviewed also show that the application of gamification elements have positive impact on student learning in the context of which they have implemented. Only one study reported that gamification brings negative impacts on student learning namely the Kyewski and Kramer [28]. According to them, gamification elements have less impact on students' motivation. This may be caused by a number of factors in their study, but it can be regarded as an isolated case in comparison with the number of studies that report a positive impact from gamification. The bar chart in Figure 1 shows a list and frequency of learning outcomes that were studied in the reviewed article which receive positive impact following the application of gamification elements. This list was based on the frequency of each learning outcome reported in Table 1.

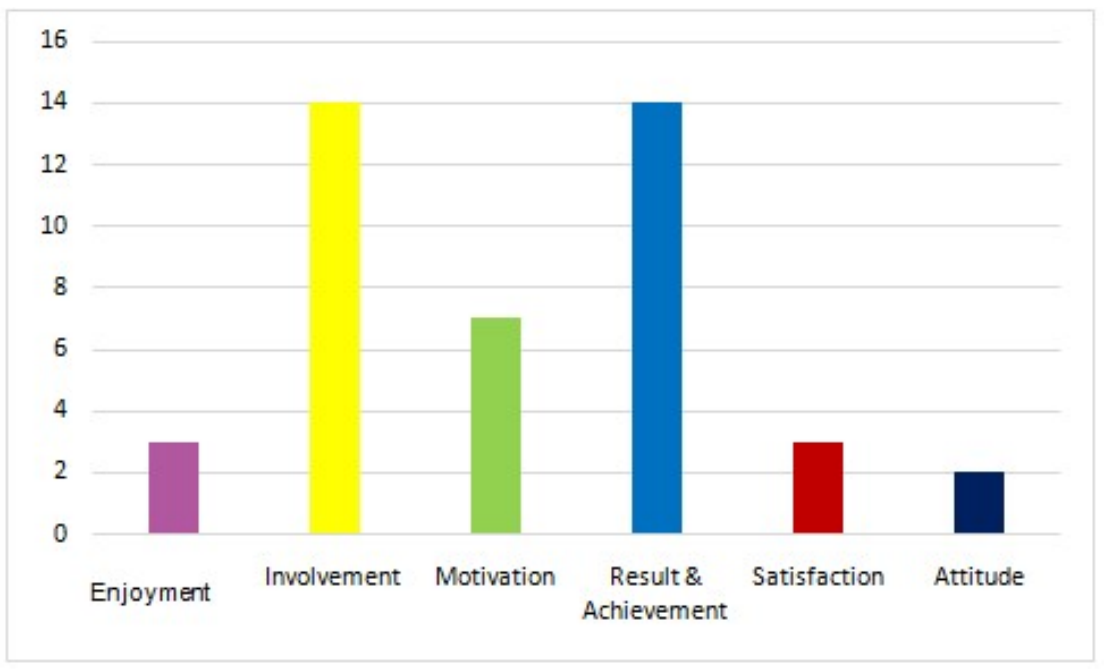

Figure 1. The list and frequencies of learning outcomes studied in the reviewed articles which receive a positive impact from gamification

The bar chart in Figure 1 clearly shows that gamification has provided a positive impact on learning outcomes in various forms such as enjoyment, engagement, motivation (intrinsic and extrinsic), results and achievements, satisfaction and attitudes. Based on the chart, the engagement and students' results and achievement most often become the focus of the study, followed by motivation in third place. The high frequency of these three items further reinforced the assumption that gamification can make students more active and motivated when learning, enabling them to achieve the best performance in the assessment of learning. It also shows that gamification can catalyze engagement and motivation (intrinsic and extrinsic), which are both indispensable in creating quality learning [31]. Meanwhile, enjoyment, satisfaction and attitudes were also receiving positive impact from gamification but there are still little researches done to further strengthen these findings.

After discussing the learning outcomes that received a positive impact from the application of gamification, we will then discuss the elements of gamification that have been applied so as to provide the positive effects. To facilitate the presentation of findings related to gamification elements obtained in Table 1, we have transformed it into a form of a bar chart in Figure 2 and it was arranged in descending order. 
The International Journal of Multimedia \& Its Applications (IJMA) Vol.10, No.6, December 2018

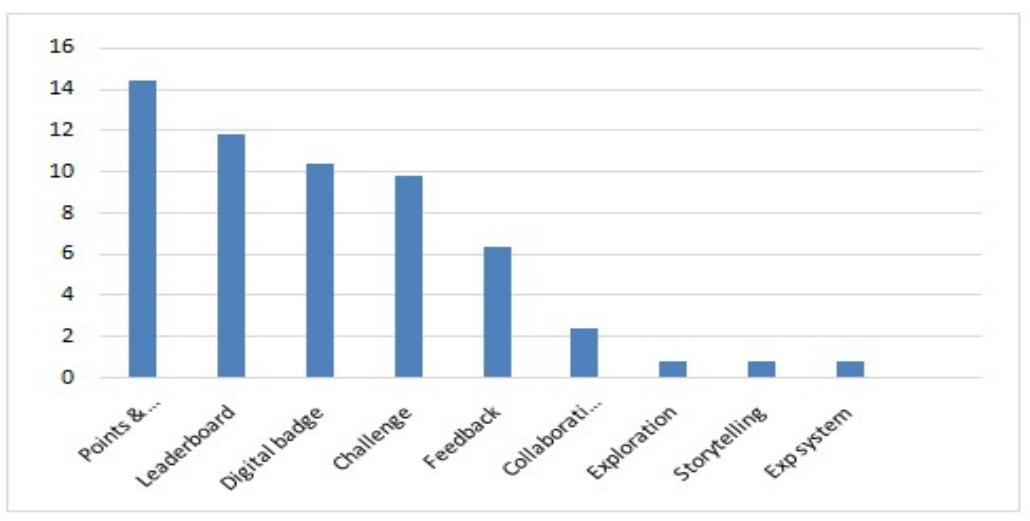

Figure 2. The elements of gamification applied in the reviewed studies

Referring to the above bar chart, gamification elements that have been applied in many studies are the points and rewards element (15 studies). Points and rewards are something that are awarded to the students who successfully answer the questions correctly, completed a given task and any other achievement [4]. Besides, elements of the leaderboard, digital badges and challenges have also recorded high frequency of usage in the reviewed studies, which were 12,10 and 9 studies respectively. Leaderboard is a section to display players' ranks while digital badge is one form of the reward. On the other hand, challenge is set of rules of the game that makes the game more challenging [4].

Based on the numbers, it means that these four elements (rewards, leaderboard, digital badge and challenge) are indispensable if we wish to create effective gamification learning activities as they have been proven by these studies. These elements are also viewed as closely related to each other and used together in support of a learning activity. For example, points element supported by the leaderboard to display ranks and points, challenge use digital badge as a reward, and so on. While elements of the experience system, storytelling and exploration viewed as a lesser choice for researchers, but they also had a positive impact in their research.

For us, it is not surprising that elements of points and rewards are the elements which are most often applied in these studies because a game is usually going to have winners and losers, so the points are needed in making its determination. Furthermore, most of the games have a goal that is often associated with points [4], such as 'Collect 100 stars to go to the next level' or 'Get 50 points to level up the character'. In addition, points and rewards are also needed in creating competition between players [7], which indirectly increases their interaction and engagement in learning. Thus, points and rewards are necessary to gamify teaching and learning activity.

In addition to the points, leaderboards also have the function to promote competition among students as well as displaying the latest ranks of students in the game [14]. It is also suitable for the current generation of students especially the $\mathrm{Z}$ generation who love to share and exhibit things related to themselves to the public [32]. Therefore, the leaderboard is crucial in gamifying an activity, hence it is not surprising that it is the second element which is often used. Through the use of the leaderboard, students will be more motivated to maintain position when they are on top while the ones who are trailing are more motivated to chase the ones on top. However, there are studies reported that the leaderboard has lowered the motivation of students who are under [8]. Therefore, its usage in a study that wants to be carried out should be properly planned. 
The International Journal of Multimedia \& Its Applications (IJMA) Vol.10, No.6, December 2018

Next, the digital badge element is also frequently applied in the reviewed studies. Same as the points and leaderboards, digital badges also function to determine the position and achievement among students with other students and provided to eligible students only [23]. But we see it as a form of reward that is more attractive because it has a unique shape and diverse, and well worth collecting by students as their personal collection. Some examples of achievements that qualify students to earn badges in the study by Hew et al. [13] is such as download notes before class starts, respond more than six times and leaderboard chart champion, where each of them has an attractive design. The use of this digital badge is in line with human nature that likes to collect a variety of items that is deemed valuable. This indirectly creates competition among students and makes them active while studying. However, if we want to use digital badges, more thought is needed in advance on whether digital badges can be seen by other students or not because based on the survey by Kyewski and Krämer [28], the findings are more positive if the earned digital badge can only be seen by its owner. However, we believe that it is necessary for the digital badges to be seen by other students, as the main function of the digital badge is to display status and achievement.

Moving on the next gamification elements in Figure 2, the elements of challenge and feedback were also often applied in the reviewed studies. We felt that the actual number for both these elements should be higher because they are among the basic elements that make up a game [4], but it was not specified by the researchers. Without challenge, a game will be boring, but if it's too challenging, it can cause students to give up [7]. Thus, we should be careful in forming the challenges in the game that will be developed later. Meanwhile, cooperation elements appear somewhat less in practice. This is because most of the studies put more emphasis on competition rather than cooperation with the establishment of a point system, leaderboards and digital badges [5], [7], [17], [28]. However this does not mean that the cooperation was not able to create competition. It can be done by creating group gamification activities where students need to cooperate among themselves in order to compete with other groups, and this is what researchers have planned to be implemented in future studies. In the meantime, elements of storytelling, exploration and exp system are less applicable and this may be because most of the games designed in such studies are not role-playing which normally contain these elements.

\section{Conclusions}

The results of this study found that gamification is able giving positive impacts on student learning from various angle especially their achievements, involvement and motivation in learning activities. Only few researchers reported negative impacts of gamification in their studies. The gamification elements which often implemented in teaching and learning activities in the reviewed studies were points and rewards, leaderboards, and digital badges. Based on this finding, we can conclude that with the use of certain game elements, gamification can bring positive outcome to students' learning and it should be widely implemented by teachers or lecturers in teaching and learning process.

Future studies need to explore gamification for early childhood education, as most of the reviewed researches were conducted for school and university students. Moreover future studies are advised to focus on other gamification elements such as collaboration, experience system and exploration together with the commonly used elements. Besides, more researches are needed to explore on students enjoyment, satisfaction and attitude towards the gamified learning activities. As for our future study, we will be studying the students' learning satisfaction and achievement 
The International Journal of Multimedia \& Its Applications (IJMA) Vol.10, No.6, December 2018

towards gamification. Other than there are still lack of researches on this area, we put our focus on satisfaction because it is one of important element in determining the effectiveness of virtual learning, as we are planning to conduct the teaching and learning activities inside a 3-D virtual world. We will also apply collaboration element in gamifying our teaching leaning processes in order to see its impacts on student learning outcomes.

\section{ACKNOWLEDGEMENTS}

This work was supported by the Geran Penyelidikan Khas Universiti Berteraskan Pendidikan (2017-0301-107-01 KHAS PENDIDIKAN) and initiated by Universiti Pendidikan Sultan Idris.

\section{REFERENCES}

[1] Dicheva, D., Dichev, C., Agre, G., \& Angelova, G. (2015). Gamification in education: A systematic mapping study. Journal of Educational Technology \& Society, 18(3), 9.

[2] Vlachopoulos, D., \& Makri, A. (2017). The effect of games and simulations on higher education: a systematic literature review. International Journal of Educational Technology in Higher Education, 14(1), 22.

[3] Google Trend (2017). Game-based learning. Retrieved from https://trends.google.com/trends/ explore? date $=$ today $\% 205$-y\&q $=$ gamebased $\% 20$ learning.

[4] Hoe, T. W. (2015). Gamifikasi dalam pendidikan: Pembelajaran berasaskan permainan. Tanjong Malim: Universiti Pendidikan Sultan Idris.

[5] Tsay, C. H. H., Kofinas, A., \& Luo, J. (2018). Enhancing student learning experience with technology-mediated gamification: An empirical study. Computers \& Education, 121, 1-17.

[6] Alsawaier, R. S. (2018). The effect of gamification on motivation and engagement. The International Journal of Information and Learning Technology, 35(1), 56-79.

[7] Chan, K. Y. G., Tan, S. L., Hew, K. F. T., Koh, B. G., Lim, L. S., \& Yong, J. C. (2017). Knowledge for games, games for knowledge: designing a digital roll-and-move board game for a law of torts class. Research and Practice in Technology Enhanced Learning, 12(1), 7.

[8] Sepehr, S., \& Head, M. (2013, October). Competition as an element of gamification for learning: an exploratory longitudinal investigation. In Proceedings of the First International Conference on Gameful Design, Research, and Applications (pp. 2-9). ACM.

[9] Szegletes, L., Koles, M., \& Forstner, B. (2015). Socio-cognitive gamification: general framework for educational games. Journal on Multimodal User Interfaces, 9(4), 395-401.

[10] Alexiou, A., \& Schippers, M. C. (2018). Digital game elements, user experience and learning: A conceptual framework. Education and Information Technologies, 1-23.

[11] Cózar-Gutiérrez, R., \& Sáez-López, J. M. (2016). Game-based learning and gamification in initial teacher training in the social sciences: an experiment with MinecraftEdu. International Journal of Educational Technology in Higher Education, 13(1), 2.

[12] González, C. S., Gómez, N., Navarro, V., Cairós, M., Quirce, C., Toledo, P., \& Marrero-Gordillo, N. (2016). Learning healthy lifestyles through active videogames, motor games and the gamification of educational activities. Computers in Human Behavior, 55, 529-551.

[13] Hew, K. F., Huang, B., Chu, K. W. S., \& Chiu, D. K. (2016). Engaging Asian students through game mechanics: Findings from two experiment studies. Computers \& Education, 92, 221-236

[14] Pesare, E., Roselli, T., Corriero, N., \& Rossano, V. (2016). Game-based learning and gamification to promote engagement and motivation in medical learning contexts. Smart Learning Environments, $3(1), 5$.

[15] Spires, H. A., \& Lester, J. C. (2016). Game-based learning: creating a multidisciplinary community of inquiry. On the Horizon, 24(1), 88-93. 
The International Journal of Multimedia \& Its Applications (IJMA) Vol.10, No.6, December 2018

[16] Barna, B., \& Fodor, S. (2017). An Empirical Study on the Use of Gamification on IT Courses at Higher Education. In International Conference on Interactive Collaborative Learning (pp. 684-692). Springer, Cham.

[17] Ding, L., Kim, C., \& Orey, M. (2017). Studies of student engagement in gamified online discussions. Computers \& Education, 115, 126-142.

[18] Dochie, E., Herman, C., \& Epure, C. (2017). Using Gamification for the Development of Soft Skills. Skill Generator Assessment Game Case Study. In The International Scientific Conference eLearning and Software for Education (Vol. 3, p. 610). "Carol I" National Defence University.

[19] Khan, A., Ahmad, F. H., \& Malik, M. M. (2017). Use of digital game based learning and gamification in secondary school science: The effect on student engagement, learning and gender difference. Education and Information Technologies, 22(6), 2767-2804.

[20] Leftheriotis, I., Giannakos, M. N., \& Jaccheri, L. (2017). Gamifying informal learning activities using interactive displays: an empirical investigation of students' learning and engagement. Smart Learning Environments, 4(1), 2.

[21] Pechenkina, E., Laurence, D., Oates, G., Eldridge, D., \& Hunter, D. (2017). Using a gamified mobile app to increase student engagement, retention and academic achievement. International Journal of Educational Technology in Higher Education, 14(1), 31.

[22] Rawendy, D., Ying, Y., Arifin, Y., \& Rosalin, K. (2017). Design and development game Chinese language learning with gamification and using mnemonic method. Procedia Computer Science, 116, 61-67.

[23] Sitra, O., Katsigiannakis, V., Karagiannidis, C., \& Mavropoulou, S. (2017). The effect of badges on the engagement of students with special educational needs: A case study. Education and Information Technologies, 22(6), 3037-3046.

[24] Yildirim, I. (2017). The effects of gamification-based teaching practices on student achievement and students' attitudes toward lessons. The Internet and Higher Education, 33, 86-92.

[25] Bovermann, K., \& Bastiaens, T. (2018, June). Using Gamification to Foster Intrinsic Motivation and Collaborative Learning: A Comparative Testing. In EdMedia+ Innovate Learning (pp. 1128-1137). Association for the Advancement of Computing in Education (AACE).

[26] Denny, P., McDonald, F., Empson, R., Kelly, P., \& Petersen, A. (2018). Empirical Support for a Causal Relationship between Gamification and Learning Outcomes. In Proceedings of the $2018 \mathrm{CHI}$ Conference on Human Factors in Computing Systems. ACM.

[27] Huang, B., Hew, K. F., \& Lo, C. K. (2018). Investigating the effects of gamification-enhanced flipped learning on undergraduate students' behavioural and cognitive engagement. Interactive Learning Environments, 1-21.

[28] Kyewski, E., \& Krämer, N. C. (2018). To gamify or not to gamify? An experimental field study of the influence of badges on motivation, activity, and performance in an online learning course. Computers \& Education, 118, 25-37.

[29] Lam, Y. W., Hew, K. F., \& Chiu, K. F. (2018). Improving argumentative writing: Effects of a blended learning approach and gamification. Language Learning \& Technology, 22(1), 97-118.

[30] White, M., \& Shellenbarger, T. (2018). Gamification of Nursing Education with Digital Badges. Nurse educator, 43(2), 78-82.

[31] Biggs, J. B. (2011). Teaching for quality learning at university: What the student does. McGraw-Hill Education (UK).

[32] Turner, A. (2015). Generation Z: Technology and social interest. The Journal of Individual Psychology, 71(2), 103-113. 
The International Journal of Multimedia \& Its Applications (IJMA) Vol.10, No.6, December 2018

\section{AUTHORS}

Dr. Mohd Hishamuddin Abdul Rahman is a senior lecturer at the Faculty of Art, Computing \& Creative Industry, Universiti Pendidikan Sultan Idris (UPSI). His research interests are towards educational technology, multimedia, virtual learning environment, game-based learning and gamification, virtual and augmented reality and also on new media in teaching and learning.

Dr. Ismail @ Ismail Yusuf Panessai is a senior lecturer at the Faculty of Art, Computing \& Creative Industry, Universiti Pendidikan Sultan Idris (UPSI). His research interests are towards Artificial Intelligence, Artificial Intelligence in education, VRP and Control System.

Dr. Noor Anida Zaria Binti Mohd Noor is a senior lecturer at the Faculty of Art, Computing \& Creative Industry, Universiti Pendidikan Sultan Idris (UPSI). Her research interests are towards Information Technology, Knowledge Management, Knowledge Integration and Project Management.

Dr. Nor Syazwani Binti Mat Salleh is a senior lecturer at the Faculty of Art, Computing \& Creative Industry, Universiti Pendidikan Sultan Idris (UPSI). Her research interests are towards ICTs in Education, Art \& Design, Graphic Design and Personalized Learning.
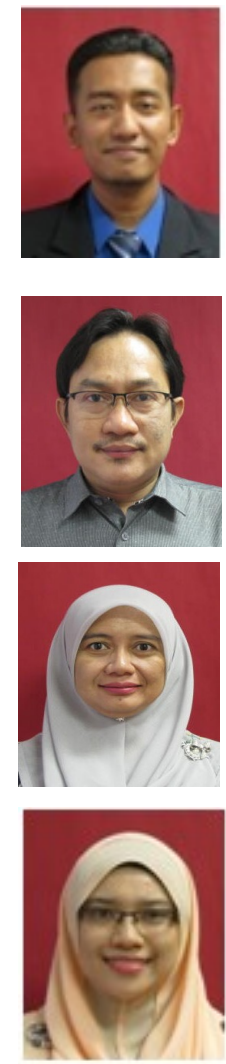